\title{
Identification of the Causative Genes of Calcium Deficiency Disorders in Horticulture Crops: A Systematic Review
}

\author{
Takanori Kuronuma * and Hitoshi Watanabe
}

check for updates

Citation: Kuronuma, T.; Watanabe, $\mathrm{H}$. Identification of the Causative Genes of Calcium Deficiency Disorders in Horticulture Crops: A Systematic Review. Agriculture 2021, 11, 906. https://doi.org/10.3390/ agriculture11100906

Academic Editor: Eiji Nishihara

Received: 8 September 2021 Accepted: 20 September 2021 Published: 22 September 2021

Publisher's Note: MDPI stays neutral with regard to jurisdictional claims in published maps and institutional affiliations.

Copyright: (C) 2021 by the authors. Licensee MDPI, Basel, Switzerland. This article is an open access article distributed under the terms and conditions of the Creative Commons Attribution (CC BY) license (https:// creativecommons.org/licenses/by/ $4.0 /)$.
Center for Environment, Health and Field Sciences, Chiba University, Chiba 277-0882, Japan; hwatanabe@faculty.chiba-u.jp

* Correspondence: t.kuronuma@chiba-u.jp

\begin{abstract}
The occurrence of calcium $\left(\mathrm{Ca}^{2+}\right)$ deficiency disorders is a severe problem in the production of horticulture crops. Recently, several studies have investigated the role of gene expression in $\mathrm{Ca}^{2+}$ deficiency disorders and/or $\mathrm{Ca}^{2+}$ accumulation, providing an indication of the mechanism of $\mathrm{Ca}^{2+}$ deficiency disorders at the genetic level. To determine the relation between gene expression and the occurrence of $\mathrm{Ca}^{2+}$ deficiency disorders, we conducted a systematic review of the literature using the Preferred Reporting Items for Systematic Reviews and Meta-analyses protocol. In our initial search, we extracted studies investigating the relationships between $\mathrm{Ca}^{2+}$ deficiency disorders (tipburn and blossom-end rot) and gene expression. In our second search, we extracted studies involving functional analyses of the genes associated with $\mathrm{Ca}^{2+}$ deficiency and/or $\mathrm{Ca}^{2+}$ accumulation in plant organs. Thirty-seven articles were extracted from both searches. Studies on $\mathrm{Ca}^{2+}$ movementrelated genes $\left(\mathrm{Ca}^{2+}\right.$ antiporters, calreticulin, $\mathrm{Ca}^{2+}$ pumps, $\mathrm{Ca}^{2+}$ channels, and pectin methylesterases) accounted for the majority of these articles. Particularly, the effects of the expression of CAXs $\left(\mathrm{Ca}^{2+} / \mathrm{H}^{+}\right.$antiporters) and CRT (calreticulin) on the occurrence of $\mathrm{Ca}^{2+}$ deficiency disorders were demonstrated in studies extracted from both searches. Further research focusing on these genes may reveal the causative genes for Ca deficiency disorders in different horticulture crops. We hope that the knowledge synthesized in this systematic review will contribute to the accumulation of further knowledge and elucidation of the causes of $\mathrm{Ca}^{2+}$ deficiency disorders.
\end{abstract}

Keywords: $\mathrm{Ca}^{2+}$ deficiency; gene expression; transcriptome; QTL; $\mathrm{Ca}^{2+}$ accumulation; $\mathrm{Ca}^{2+}$ antiporter; $\mathrm{Ca}^{2+}$ channel; $\mathrm{Ca}^{2+}$ pump; $\mathrm{Ca}^{2+}$ binding protein

\section{Introduction}

Calcium $\left(\mathrm{Ca}^{2+}\right)$ is an essential plant macronutrient, mainly transported via the xylem in the transpiration stream [1]. However, its mobility from older plant organs to newly developed tissues is poor. Thus, $\mathrm{Ca}^{2+}$ deficiency disorders often occur in new leaves and fruits even when sufficient $\mathrm{Ca}^{2+}$ is supplied in the field [2,3]. The occurrence of $\mathrm{Ca}^{2+}$ deficiency disorders is a serious concern in horticulture crop production because it causes significant economic losses [4-6].

Two $\mathrm{Ca}^{2+}$ deficiency disorders, tipburn and blossom-end rot (BER), have been studied since the 1800s, and it is becoming clearer how environmental conditions (e.g., humidity $[7,8]$, light $[5,9]$, and air flow $[10,11])$ can mitigate the damage caused by these disorders. However, no environmental control techniques to eliminate the occurrence of $\mathrm{Ca}^{2+} \mathrm{de}-$ ficiency disorders have been found, and farmers instead often force the selection and production of cultivars with high resistance to $\mathrm{Ca}^{2+}$ deficiency disorders.

In Arabidopsis, many $\mathrm{Ca}^{2+}$ transporter and binding protein-encoding genes have been identified [12-14], and their functions have been extensively demonstrated by functional analysis $[15,16]$. These findings have contributed to increased clarity in the understanding of plant $\mathrm{Ca}^{2+}$ signaling systems [17-19]. Moreover, an increasing number of studies have utilized transcriptome or QTL (quantitative trait locus) analysis to identify the causative 
genes of $\mathrm{Ca}^{2+}$ deficiency disorders. Some studies have also performed functional analyses of the genes associated with $\mathrm{Ca}^{2+}$ deficiency $[20,21]$.

To synthesize the current knowledge regarding the role of gene expression in the occurrence of $\mathrm{Ca}^{2+}$ deficiency disorders, we conducted a systematic literature review using Preferred Reporting Items for Systematic Reviews and Meta-analyses (PRISMA) [22]. In this review, we focused on plants exhibiting symptoms of two $\mathrm{Ca}^{2+}$ deficiency disorders, tipburn and BER. We firstly extracted studies that investigated the relationship between gene expression and these disorders, and secondly studies in which a functional analysis of the genes associated with $\mathrm{Ca}^{2+}$ deficiency and/or $\mathrm{Ca}^{2+}$ accumulation in plant organs was conducted. The information synthesized in this review will contribute to future research on the causative genes of $\mathrm{Ca}^{2+}$ deficiency.

\section{Methods}

This systematic review was conducted following the PRISMA principles [22], and we referred to several other systematic reviews [23-26]. Web of Science and PubMed were selected as the scholarly online databases. The publication date of the articles was set from 1 January 1983 to 7 June 2021 (the date on which the last search was conducted). Firstly, to capture all empirical studies that used genetic analysis to identify the causative genes for Ca deficiency disorders, we used the following search terms with multiple combinations: "Tipburn" OR "blossom end rot" AND "gene expression" OR "transcriptome" OR "QTL." We defined this search as Search 1. For our second search (defined as Search 2), to capture all studies involving the functional analysis of genes associated with $\mathrm{Ca}^{2+}$ deficiency and/or $\mathrm{Ca}^{2+}$ accumulation at the plant organ level, we used the following search terms: "transgenic plant" and "calcium deficiency".

After document retrieval, we read the titles and abstracts of all the articles and removed duplicate articles. The full text of an article was reviewed if the title and abstract met the purpose of each literature search (see above for details). Only articles written in English and published as original articles were extracted. When we searched for studies that investigated the causative genes for $\mathrm{Ca}^{2+}$ deficiency disorders by conducting genetic analysis (Search 1), we focused only on two $\mathrm{Ca}^{2+}$ deficiency disorders, namely, tipburn and blossom-end rot (BER). Additionally, when extracting studies involving the functional analysis of genes associated with $\mathrm{Ca}^{2+}$ deficiency disorders and/or $\mathrm{Ca}^{2+}$ accumulation (Search 2), we considered only those that demonstrated clear results at the plant organ level (i.e., articles that demonstrated gene function associated with $\mathrm{Ca}$ accumulation at the cellular level were excluded).

\section{Results and Discussion}

3.1. Search 1: Studies Using Genetic Analysis to Identify the Causative Genes for $\mathrm{Ca}^{2+}$ Deficiency Disorders (Tipburn and BER)

A total of 64 articles were obtained through document retrieval (Figure 1). After removal of duplicate articles $(n=23)$ and review articles $(n=4), 37$ articles were selected for full-text evaluation. Following the eligibility evaluation, 15 articles were determined as eligible for this systematic review. The 15 extracted articles were organized by plant materials and $\mathrm{Ca}^{2+}$ deficiency disorders (tipburn or BER), as shown in Table 1. Given below is a review of the experimental results for each deficiency disorder and plant type.

\subsubsection{Tipburn in Lettuce}

Four studies investigated the causative genes of tipburn in lettuce by conducting QTL and transcriptome analyses (Table 1). In 2013, Jenni et al. [27] conducted QTL analysis to determine the genetic basis of heat stress-induced physiological disorders (including tipburn incidence and severity) in lettuce. This study was the first to analyze the relevance of tipburn and its genetic basis in lettuce. A single QTL, qTPB5.2 on LG (linkage group) 5b, was detected in multiple trials, and described $38-70 \%$ of the variation in tipburn incidence. Macias-González et al. [28] conducted multiple large-scale QTL analyses in different years 
and growing environments. They reported two major QTLs for tipburn (including $q$ TPB5.2 on LG $5 b$ ), which determined up to $45 \%$ and $65 \%$ of the phenotypic variance, respectively. The latest research by the authors [29] identified 12 genes in qTPB5.2 as candidate genes for tipburn resistance. The authors identified these candidate genes by dissecting the QTL (qTPB5.2) using multiple RIL (recombinant inbred line) populations. In addition, two of the 12 genes were found to encode proteins with a sequence similarity to Ca transporters.

In contrast, Seki et al. [30] conducted a QTL analysis to investigate the relationship between leaf shape and tipburn incidence. They used Empire-type (serrated leaf) cultivars and Salinas-type (wavy leaf) cultivars in the field cultivation test. The Empire-type cultivars showed late bolting and high tipburn susceptibility compared with the Salinas-type cultivars. Their research revealed that leaf shape and bolting time were controlled by a single locus in LG5. In addition, using further fine mapping and transcriptome analysis, the authors identified LSTCP4 as a candidate gene for both traits (leaf shape and bolting time). Therefore, the authors suggested that the trait of tipburn incidence may also be controlled by LSTCP4.

\section{Search 1: Studies using genetic analysis to identify causative genes for} $\mathrm{Ca}^{2+}$ deficiency disorders (tipburn and BER)

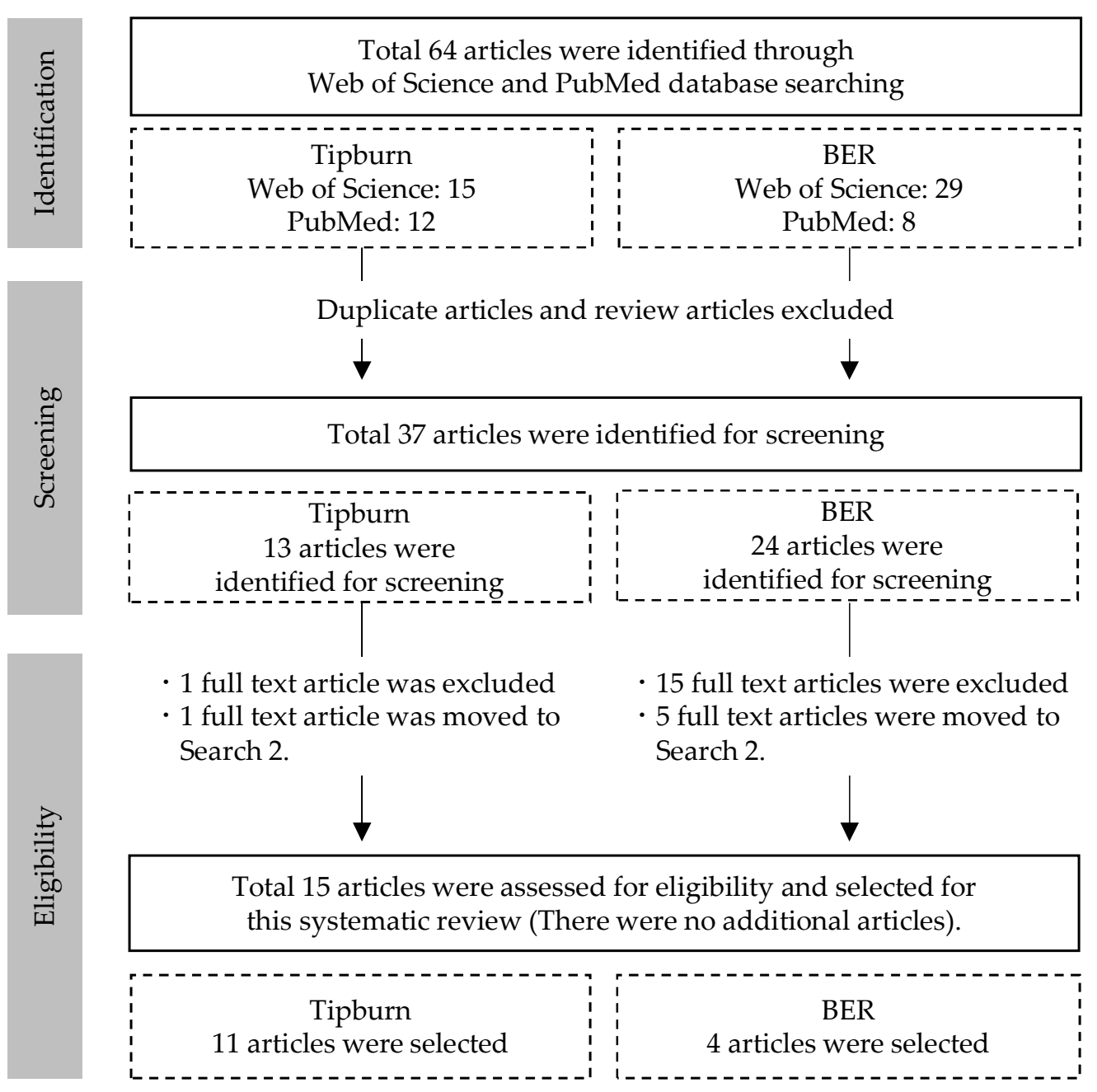

Figure 1. Systematic review flow chart for Search 1. 
Table 1. Overview of the studies using genetic analysis to identify the causative genes of $\mathrm{Ca}^{2+}$ deficiency disorders (tipburn and BER) obtained via Search 1 .

\begin{tabular}{|c|c|c|c|c|c|c|c|}
\hline Year & Author & Plant Materials & $\begin{array}{l}\mathrm{Ca}^{2+} \text { Deficiency } \\
\text { Disorder }\end{array}$ & Main Methods & Main Comparison & Causal Candidate Genes & Ref No. \\
\hline 2013 & Jenni et al. & $\begin{array}{l}\text { Lettuce } \\
\text { (Lactuca sativa L.) } \\
\text { leaves }\end{array}$ & Tipburn & QTL mapping & $\begin{array}{c}\text { Empire type vs. Salinas type } \\
\text { (Genetic mapping was conducted } \\
\text { using } 152 \mathrm{~F}_{7} \text { RIL (recombinant inbred } \\
\text { line) populations developed from an } \\
\text { intra-specific cross of the Empire type } \\
\times \text { Salinas type) }\end{array}$ & $\begin{array}{c}q T P B 5.2 \text { on LG } 5 b \text { (largest tipburn } \\
\text { QTL) }\end{array}$ & [27] \\
\hline 2019 & $\begin{array}{l}\text { Macias-González } \\
\text { et al. }\end{array}$ & $\begin{array}{c}\text { Lettuce } \\
\text { (Lactuca sativa L.) } \\
\text { leaves }\end{array}$ & Tipburn & QTL mapping & $\begin{array}{l}\text { Seven RIL populations were analyzed } \\
\text { in multiple environments and years. }\end{array}$ & $\begin{array}{c}\text { Two major QTLs for tipburn incidence } \\
\text { were identified in LG1 } \\
\text { (qTBIN_1_QC11) and LG5 (qTPB5.2). }\end{array}$ & [28] \\
\hline 2021 & $\begin{array}{l}\text { Macias-González } \\
\text { et al. }\end{array}$ & $\begin{array}{l}\text { Lettuce } \\
\text { (Lactuca sativa L.) } \\
\text { leaves }\end{array}$ & Tipburn & $\begin{array}{l}\text { QTL mapping } \\
\text { RNA-seq }\end{array}$ & $\begin{array}{l}\text { Eleven RIL population were analyzed } \\
\text { in multiple environments and years. }\end{array}$ & $\begin{array}{l}12 \text { candidate genes including Ca } \\
\text { transporter genes in } q T P B 5.2 .\end{array}$ & [29] \\
\hline 2020 & Seki et al. & $\begin{array}{l}\text { Lettuce } \\
\text { (Lactuca sativa L.) } \\
\text { leaves }\end{array}$ & Tipburn & $\begin{array}{l}\text { ddRAD-seq } \\
\text { QTL mapping } \\
\text { RNA-seq } \\
\text { Real-time PCR }\end{array}$ & $\begin{array}{c}\text { Empire type (serrated leaf) vs. Salinas } \\
\text { type (wavy leaf) } \\
\text { (Genetic mapping was conducted } \\
\text { using } F_{2} \text { population derived from a } \\
\text { cross between the Empire-type } \\
\text { cultivar and Salinas-type cultivar.) }\end{array}$ & $\begin{array}{c}\text { LsTCP4 (Lsat_1_v5_gn_5_127021 } \\
\text { locus) }\end{array}$ & [30] \\
\hline 2016 & Su et al. & $\begin{array}{l}\text { Chinese cabbage } \\
\text { (Brassica rapa L. } \\
\text { ssp. pekinensis) } \\
\text { leaves }\end{array}$ & Tipburn & Real-time PCR & $\begin{array}{l}\text { Tipburn-susceptible inbred line vs. } \\
\text { tipburn-resistant inbred line }\end{array}$ & $\begin{array}{c}\mathrm{Ca}^{2+} \text { transporter genes } \\
\text { (e.g., } C A X 1 \text { orthologs }(\text { Bra005131 and } \\
\text { Bra017134)) }\end{array}$ & [31] \\
\hline 2019 & Su et al. & $\begin{array}{l}\text { Chinese cabbage } \\
\text { (Brassica rapa L. } \\
\text { ssp. pekinensis) } \\
\text { leaves }\end{array}$ & Tipburn & $\begin{array}{l}\text { GWA mapping } \\
\text { QTL mapping } \\
\text { Functional analysis }\end{array}$ & $\begin{array}{l}\text { Tipburn-susceptible plants vs. } \\
\text { Tipburn-resistant plants } \\
\text { (Genetic mapping was conducted } \\
\text { using } 194 \text { divers inbred lines, a } \\
\text { doubled haploid (DH100) population, } \\
\text { and an } \mathrm{F}_{2} \text { population) }\end{array}$ & BraCRT2 (Bra018575) & [32] \\
\hline
\end{tabular}


Table 1. Cont.

\begin{tabular}{|c|c|c|c|c|c|c|c|}
\hline Year & Author & Plant Materials & $\begin{array}{c}\mathrm{Ca}^{2+} \text { Deficiency } \\
\text { Disorder }\end{array}$ & Main Methods & Main Comparison & Causal Candidate Genes & Ref No. \\
\hline 2019 & Wang et al. & $\begin{array}{l}\text { Chinese cabbage } \\
\text { (Brassica rapa } \mathrm{L} \text {. } \\
\text { ssp. pekinensis) } \\
\text { leaves }\end{array}$ & Tipburn & $\begin{array}{l}\text { circRNA } \\
\text { sequencing } \\
\text { qRT-PCR }\end{array}$ & $\begin{array}{c}\mathrm{Ca}_{2+} \text { deficiency treatments } \\
(0,3 \text {, and } 6 \text { day after treatment })\end{array}$ & $\begin{array}{c}\text { ABF2 (Bra040260) et al. } \\
\text { (23 and } 22 \text { circRNAs differentially } \\
\text { expressed) }\end{array}$ & [33] \\
\hline 2013 & Lee et al. & $\begin{array}{c}\text { Cabbage } \\
\text { (Brassica oleracea) } \\
\text { leaves (apex, } \\
\text { middle, and base) }\end{array}$ & Tipburn & Real-time PCR & $\begin{array}{l}\text { Tipburn-susceptible line vs. } \\
\text { tipburn-resistant line }\end{array}$ & $\begin{array}{c}\mathrm{Ca}^{2+} \text { transporter genes } \\
\text { (e.g., BoCAX2 and BoCAX5) }\end{array}$ & {$[34]$} \\
\hline 2016 & Lee et al. & $\begin{array}{c}\text { Cabbage } \\
\text { (Brassica oleracea } \\
\text { var. capitana) } \\
\text { leaves (apex, } \\
\text { middle, and base) }\end{array}$ & Tipburn & RNA-seq & $\begin{array}{l}\text { Tipburn-susceptible cabbage vs. } \\
\text { tipburn-resistant cabbage vs. Kale }\end{array}$ & $\begin{array}{l}1844 \text { loci were identified as tipburn } \\
\text { related phenotype genes }\end{array}$ & {$[35]$} \\
\hline 2020 & Gonzalo et al. & $\begin{array}{l}\text { Tomato } \\
\text { (Solanum } \\
\text { lycopersicum cv. } \\
\text { 'Moneymaker' } \times \\
\text { S. pimpinellifolium } \\
\text { accession TO-937) }\end{array}$ & Tipburn & QTL mapping & $\begin{array}{c}\text { Temperature treatments } \\
\text { (T1: } 25^{\circ} \mathrm{C} \text { day } / 20^{\circ} \mathrm{C} \text { night; } \\
\text { T2: } 30^{\circ} \mathrm{C} \text { day } / 25^{\circ} \mathrm{C} \text { night; } \\
\text { T3: } 35^{\circ} \mathrm{C} \text { day } / 30^{\circ} \mathrm{C} \text { night) } \\
\text { (Genetic mapping was conducted } \\
\text { using } 168 \text { RILs and } 52 \text { Introgression } \\
\text { Line (IL)) }\end{array}$ & a QTL located in chromosome 7 & {$[36]$} \\
\hline 2021 & $\begin{array}{l}\text { Kuronuma and } \\
\text { Watanabe }\end{array}$ & $\begin{array}{c}\text { Lisianthus } \\
\text { (Eustoma } \\
\text { grandiflorum (Raf.) } \\
\text { Shinn.) } \\
\text { leaves and roots }\end{array}$ & Tipburn & RNA-seq & $\begin{array}{l}\text { Tipburn-susceptible cultivar, which } \\
\text { accumulated excessive Ca in roots, vs. } \\
\text { tipburn-resistant cultivar }\end{array}$ & $\begin{array}{c}\mathrm{Ca}^{2+} \text { transporter genes (e.g., } C A X 5 \\
\text { and } A C A 12 \text { ) and PMEs }\end{array}$ & [37] \\
\hline 2012 & Freitas et al. & $\begin{array}{l}\text { Tomato } \\
\text { Solanum } \\
\text { lycopersicum L. } \\
\text { pericarp }\end{array}$ & BER & $\begin{array}{l}\text { Real-time PCR } \\
\text { Functional analysis }\end{array}$ & $\begin{array}{l}\text { Gibberellin (GA) treatments } \\
\text { (Control (water), GA } 4+7 \text {, and } \\
\text { prohexadione-calcium (GA } \\
\text { biosynthesis inhibitor)) }\end{array}$ & $\begin{array}{l}C A X \text { and } C a^{2+}-A T P a s e \text { genes } \\
\left.\text { (e.g., } C A X 3 \text { and } C a^{2+}-A T P a s e 1\right)\end{array}$ & [38] \\
\hline
\end{tabular}


Table 1. Cont

\begin{tabular}{|c|c|c|c|c|c|c|c|}
\hline Year & Author & Plant Materials & $\begin{array}{c}\mathrm{Ca}^{2+} \text { Deficiency } \\
\text { Disorder }\end{array}$ & Main Methods & Main Comparison & Causal Candidate Genes & Ref No. \\
\hline 2018 & Freitas et al. & $\begin{array}{l}\text { Tomato } \\
\text { Solanum } \\
\text { lycopersicum L. } \\
\text { pericarp }\end{array}$ & BER & $\begin{array}{l}\text { Microarray } \\
\text { Real-time PCR }\end{array}$ & $\begin{array}{c}\text { Growth regulator treatments } \\
\text { (Control (water), GA } 4+7, \\
\text { prohexadione-calcium (GA } \\
\text { biosynthesis inhibitor), and } \mathrm{ABA})\end{array}$ & $\begin{array}{l}35 \text { candidate genes inhibiting BER } \\
\text { and } 7 \text { candidate genes triggering BER }\end{array}$ & [39] \\
\hline 2012 & Uozumi et al. & $\begin{array}{l}\text { Tomato } \\
\text { Solanum } \\
\text { lycopersicum L. } \\
\text { pericarp }\end{array}$ & BER & $\begin{array}{l}\text { Growth assay using } \\
\text { introgression lines }\end{array}$ & $\begin{array}{l}\text { IL8-3 vs. the S. lycopersicum parent } \\
\text { (M82d) }\end{array}$ & $\begin{array}{l}\text { the IL8-3 region of the S. pennellii } \\
\text { genome }\end{array}$ & [40] \\
\hline 2016 & Ikeda et al. & $\begin{array}{l}\text { Tomato } \\
\text { Solanum pennellii } \\
\text { pericarp }\end{array}$ & BER & Real-time PCR & $\begin{array}{l}\text { BER-resistant introgression line } \\
\text { (IL8-3) vs. the parent ('M82'), which is } \\
\text { a BER-susceptible cultivar. }\end{array}$ & $\begin{array}{l}\mathrm{Ca}^{2+} \text {-movement-related genes } \\
\text { (e.g., CAX4, } \mathrm{Ca}^{2+}-A T P a s e 3 \text {, and } \\
\text { Solyc07g062700 (NCX)) }\end{array}$ & [41] \\
\hline
\end{tabular}




\subsubsection{Tipburn in Chinese Cabbage}

Three studies investigating the causative genes for tipburn in Chinese cabbage were extracted (Table 1). Su et al. [31] examined the expression of $12 \mathrm{Ca}^{2+}$ transporter genes in tipburn-susceptible and tipburn-resistant plants under different $\mathrm{Ca}^{2+}$ concentrations. Most of the $\mathrm{Ca}^{2+}$ transporter genes were expressed at lower levels in the inner leaves of tipburn-susceptible plants than those in the inner leaves of tipburn-resistant plants. Additionally, salicylic acid (SA) levels were higher in tipburn-susceptible plants than in tipburn-resistant plants. These results suggest that cytoplasmic $\mathrm{Ca}^{2+}$ fluctuation-induced downstream signaling events (including SA biosynthesis) are related to tipburn resistance and response to $\mathrm{Ca}^{2+}$ deficiency conditions in Chinese cabbage. Furthermore, in 2019, the same authors conducted GWA (genome-wide association) mapping and QTL mapping using 194 diverse inbred lines, a doubled haploid (DH100) population, and an $\mathrm{F}_{2}$ population [32]. This research identified a novel tipburn-associated locus ( $g q b T R A 06)$ and found that $B r C R T 2$ (Bra018575, CRT: calreticulin) exhibited higher expression levels during the disease development. Subsequent functional analysis of BrCRT2 suggested that BrCRT2 is a candidate gene for controlling tipburn in Chinese cabbage.

One study investigated the relevance of circular RNA (circRNA) expression and response to tipburn in Chinese cabbage [33]. Circular RNAs are non-coding RNAs that play significant roles in the function and transcriptional regulation of microRNA. Wang et al. [33] conducted circRNA sequencing and showed that circRNAs were differentially expressed in response to different stages of tipburn damage. The authors also suggested that $A B F 2$, which is a host gene of differentially expressed circRNA and a positive regulator of the abiotic stress response and abscisic acid (ABA)-dependent pathway, is a key gene in the tipburn response process, since they found that $\mathrm{ABA}$ also accumulated during $\mathrm{Ca}^{2+}$ deficiency stress.

\subsubsection{Tipburn in Cabbage}

Lee et al. conducted two studies investigating causative genes of tipburn in cabbage $[34,35]$. In 2013, the authors investigated the expression of $\mathrm{Ca}^{2+}$ transporter genes in tipburn-susceptible and tipburn-resistant lines [34]. Interestingly, the authors found that BoCAX2 (CAX: $\mathrm{Ca}^{2+} / \mathrm{H}^{+}$antiporter) and BoCAX5 were differentially expressed in the tipburn-susceptible and tipburn-resistant lines. However, clear relevance of the expression of these genes and $\mathrm{Ca}^{2+}$ concentration in vacuoles was not observed. In 2016, the same authors conducted RNA-seq (RNA sequencing) using tipburn-susceptible cabbage, tipburnresistant cabbage, and kale samples, from which they identified 1844 loci as tipburn-related phenotype-specific genes [35]. Of these, 16 were specific to tipburn-susceptible cabbage, while 747 were specific to tipburn-resistant cabbage.

\subsubsection{Tipburn in the Other Horticulture Crops}

To obtain insight into the genetic control of heat tolerance in tomato plants, Gonzalo et al. [36] investigated QTLs involved in reproductive traits and tipburn incidence under different temperature treatments. A QTL located on chromosome 7 was identified as associated with a low incidence of tipburn.

In lisianthus, Kuronuma and Watanabe [37] conducted RNA-seq using both tipburnsusceptible cultivars, which accumulated excessive $\mathrm{Ca}^{2+}$ in roots [42,43], and tipburnresistant cultivars. Of the $\mathrm{Ca}^{2+}$ transporter genes, $C A X 5$ was upregulated and $A C A 12$ (ACA: $\mathrm{Ca}^{2+}$-ATPase) was downregulated in the roots of the tipburn-susceptible cultivar. Thus, the authors suggested that $C A X 5$ and $A C A 12$ are candidate genes associated with excessive $\mathrm{Ca}^{2+}$ accumulation in the roots of the tipburn-susceptible cultivar, which inhibits $\mathrm{Ca}^{2+}$ distribution to the leaves. 


\subsubsection{Blossom-End Rot in Tomato}

Four studies have been conducted on the causative genes of BER in tomatoes. In 2012, Freitas et al. [38] investigated the expression of the $\mathrm{Ca}^{2+}$ transporter genes under different gibberellin (GA) treatments. The authors found that GA treatment enhanced the expression of putative $C A X$ and $C a^{2+}-A T P a s e$ genes. Consequently, the water-soluble apoplastic $\mathrm{Ca}^{2+}$ concentration was reduced and the BER incidence increased in plants treated with GA. In 2018, the authors attempted to identify the candidate genes and gene networks that inhibit or trigger BER [39]. Candidate genes that inhibit or trigger BER were identified through a correlation analysis between the gene expression levels and BER incidence. The authors suggested that the GA synthesis inhibitor and ABA reduced BER because of increased tissue resistance to reactive oxygen species (ROS) and other toxic compounds (i.e., GA triggered BER by increasing the levels of fruit oxidative stress).

To explore agriculturally useful traits, including salt tolerance and resistance to BER, Uozumi et al. [40] used an introgression line (IL), IL8-3, in which a Solanum pennellii chromosomal segment was introgressed into Solanum lycopersicum chromosome 8 . The IL8-3 line exhibited a significantly lower incidence of BER and higher $\mathrm{Ca}^{2+}$ concentration in fruits than the 'M82d' parent line did. Thus, a gene that enhances tolerance to BER is likely to be present in the IL8-3 region of the $S$. pennellii genome. Using similar plants, Ikeda et al. [41] compared the $\mathrm{Ca}^{2+}$ concentrations and expression levels of the $\mathrm{Ca}^{2+}$ movement-related genes in IL8-3 (BER resistant introgression line) and the parent line ('M82'). Ca concentrations were higher in the fruit and leaves of IL8-3 than in those of 'M82'. Additionally, the expression level of CAX4 was significantly higher in IL8-3 than in M82. Accordingly, it was suggested that the expression levels of the $\mathrm{Ca}^{2+}$-movement-related genes are heavily involved in the development of BER by promoting $\mathrm{Ca}^{2+}$ transfer.

\subsection{Search 2: Studies Involving Functional Analysis of Genes Associated with $\mathrm{Ca}^{2+}$ Deficiency Disorders and/or $\mathrm{Ca}^{2+}$ Accumulation in Plant Organs}

A total of 103 articles were obtained through document retrieval (Figure 2). After removal of duplicate articles $(n=16)$, review articles $(n=9)$, and articles written in languages other than English $(n=1), 77$ articles were selected for full-text evaluation. Fourteen of these were extracted following eligibility evaluation. Additionally, five full-text articles were added through references and three full-text articles were added from Search 1 . The 22 articles selected for this systematic review are shown in Table 2. Given below is a review of the experimental results for each gene.

\subsubsection{Effects of Genes Encoding $\mathrm{Ca}^{2+}$ Antiporters}

Nine of the extracted studies involved functional analysis of the genes encoding tonoplast localized $\mathrm{Ca}^{2+} / \mathrm{H}^{+}$antiporters (CAXs), which are associated with $\mathrm{Ca}^{2+}$ deficiency disorders and/or $\mathrm{Ca}^{2+}$ accumulation in plant organs (Table 2). In 1999, Hirschi [20] created transgenic tobacco plants expressing Arabidopsis CAX1. The CAX1-expressing tobacco showed significantly higher $\mathrm{Ca}^{2+}$ accumulation in roots and leaves than vector control plants did. However, CAX1-expressing plants also displayed symptoms of $\mathrm{Ca}^{2+}$ deficiency (leaf necrosis). To our knowledge, this study was the first to conduct a functional analysis of the genes associated with $\mathrm{Ca}^{2+}$ deficiency disorders and $\mathrm{Ca}^{2+}$ accumulation at the plant organ level.

In tomatoes, Park et al. [21] created transgenic plants expressing $s C A X 1$ and $C A X 4$ and found that the transgenic plants contained significantly more $\mathrm{Ca}^{2+}$ than vector controls did. In contrast, only the $s C A X 1$-expressing tomatoes showed a significant increase in the occurrence of BER. Cheng et al. [44] reported that $s C A X 2 A$-expressing tomato exhibited a significantly higher $\mathrm{Ca}^{2+}$ concentration in fruit compared with the wild-type, despite there being no observed differences in morphological traits between the $s C A X 2 A$-expressing tomato and the wild-type, and no increase in BER incidence in the $s C A X 2 A$-expressing tomatoes. Freitas et al. [45] identified the reason that the $s C A X 1$-expressing tomato exhibited increased the BER incidence despite accumulating more $\mathrm{Ca}^{2+}$ than that in the 
wild-type. To do this, the authors investigated gene expression and localization of $\mathrm{Ca}^{2+}$ in the cells. The $s C A X 1$-expressing tomato was found to have accumulated excessive $\mathrm{Ca}^{2+}$ in the vacuole, and thus contained lower apoplastic and cytosolic $\mathrm{Ca}^{2+}$ concentrations than the wild-type did. These results clearly indicated that high expression of $s C A X 1$ reduces the mobility of $\mathrm{Ca}^{2+}$, which leads to the development of BER in fruits.

Park et al. [46] conducted the first attempts to use biotechnology to increase the $\mathrm{Ca}^{2+}$ content in potato tubers. In both leaves and tubers, $\mathrm{Ca}^{2+}$ accumulation was significantly higher in transgenic $s C A X 1$-expressing potatoes than in the wild-type control. Similarly, Kim et al. [47] demonstrated that $C A X 2 B$-expressing potato accumulated $50-60 \%$ more $\mathrm{Ca}^{2+}$ in tubers than the wild-type did. In these two reports, no deleterious alternations in plant growth and morphological traits between transgenic plants and wild types were observed. In contrast, Zorrilla et al. [48] and Gao et al. [49] reported that $s C A X$-expressing potatoes showed shoot rip necrosis and hollow heart, while the total and tuber $\mathrm{Ca}^{2+}$ concentrations were higher than those of the wild-type. The authors demonstrated that this result was due to $S C A X$-expressing potatoes sequestering $\mathrm{Ca}^{2+}$ in vacuoles as calcium oxalate crystals, reducing the water-soluble $\mathrm{Ca}^{2+}$ concentration.

\section{Search 2: Studies involving functional analysis of genes associated with $\mathrm{Ca}^{2+}$ deficiency disorders and/or $\mathrm{Ca}^{2+}$ accumulation in plant organs}

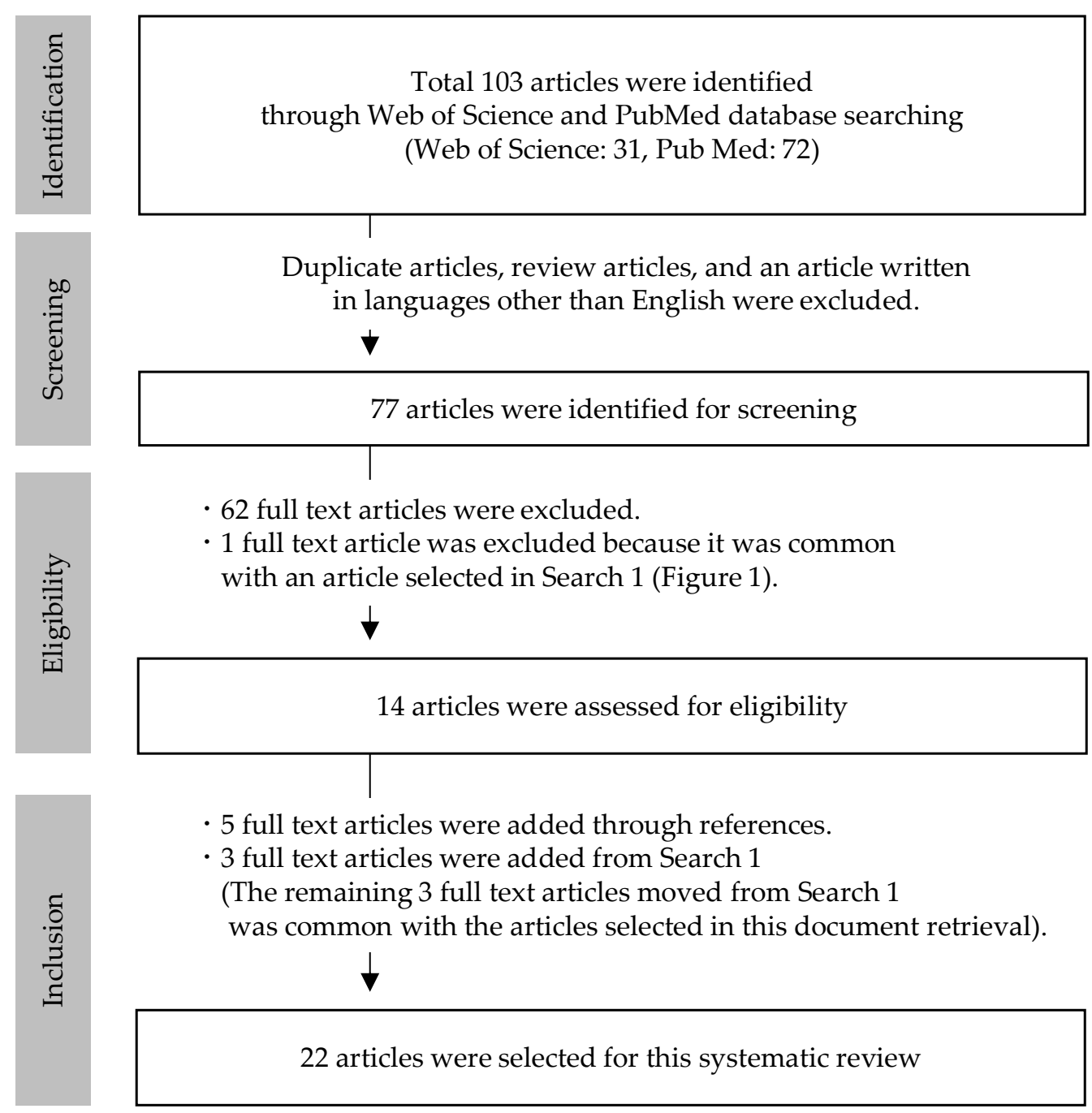

Figure 2. Systematic review flow chart for Search 2. 
Table 2. Overview of the studies involving the functional analysis of genes associated with $\mathrm{Ca}^{2+}$ deficiency disorders and Ca ${ }^{2+}$ accumulation in plant organs obtained via Search 2 .

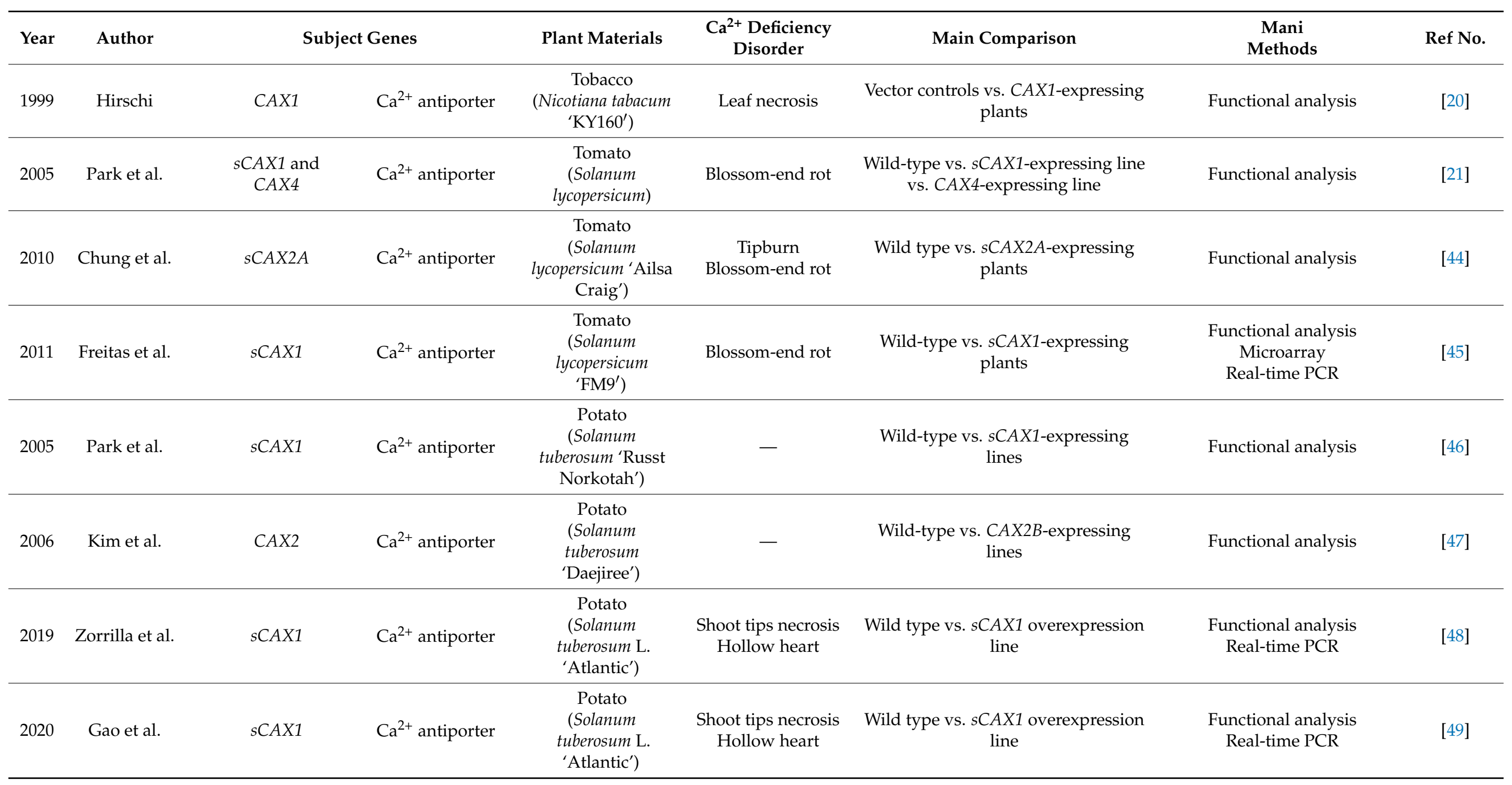


Table 2. Cont.

\begin{tabular}{|c|c|c|c|c|c|c|c|c|}
\hline Year & Author & \multicolumn{2}{|c|}{ Subject Genes } & \multirow{2}{*}{$\begin{array}{l}\text { Plant Materials } \\
\text { Carrot } \\
\text { (Daucus carota } \\
\left.\text { 'Danver } 60^{\prime}\right)\end{array}$} & \multirow{2}{*}{$\begin{array}{c}\mathrm{Ca}^{2+} \text { Deficiency } \\
\text { Disorder } \\
- \\
-\end{array}$} & \multirow{2}{*}{$\begin{array}{c}\text { Main Comparison } \\
\begin{array}{l}\text { Vector control vs. CAX1-expressing } \\
\text { line }\end{array}\end{array}$} & \multirow{2}{*}{$\begin{array}{c}\text { Mani } \\
\text { Methods }\end{array}$} & \multirow{2}{*}{$\begin{array}{c}\text { Ref No. } \\
{[50]}\end{array}$} \\
\hline 2004 & Park et al. & CAX1 & $\mathrm{Ca}^{2+}$ antiporter & & & & & \\
\hline 2001 & Persson et al. & CRT (Zea mays) & Calreticulin & $\begin{array}{l}\text { Tobacco (Nicotiana } \\
\text { tabacum 'NT1') }\end{array}$ & - & $\begin{array}{l}\text { Wild-type vs. CRT-overproducing } \\
\text { line }\end{array}$ & Functional analysis & {$[51]$} \\
\hline 2002 & Wyatt et al. & $C R T$ & Calreticulin & Arabidopsis thaliana & - & $\begin{array}{l}\text { Wild type vs. plants induced the } \\
\text { mGFP5-CRT C-domain fusion } \\
\text { protein }\end{array}$ & Functional analysis & {$[52]$} \\
\hline \multirow{2}{*}{2012} & \multirow{2}{*}{ Wu et al. } & \multirow{2}{*}{$C R T$ and $s C A X 1$} & \multirow{2}{*}{$\begin{array}{l}\text { Calreticulin and } \\
\mathrm{Ca}^{2+} \text { antiporter }\end{array}$} & $\begin{array}{l}\text { Tobacco (Nicotiana } \\
\text { tabacum 'KY160') }\end{array}$ & $\begin{array}{l}\text { Necrosis on the } \\
\text { tips of the new } \\
\text { leaves }\end{array}$ & \multirow{2}{*}{$\begin{array}{l}\text { sCAX1-expressing plants vs. } s C A X 1 \\
\text { and } C R T \text {-co-expressing plants }\end{array}$} & \multirow{2}{*}{ Functional analysis } & \multirow{2}{*}{ [53] } \\
\hline & & & & $\begin{array}{l}\text { Tomato (Solanum } \\
\text { lycopersicum } \\
\text { 'Rubion') }\end{array}$ & $\begin{array}{l}\text { Necrosis in leaf } \\
\text { tips } \\
\text { BER } \\
\end{array}$ & & & \\
\hline 2007 & Mills et al. & $E C A 3$ & $\mathrm{Ca}^{2+}$-ATPase & Arabidopsis thaliana & - & $\begin{array}{l}\text { Wild type vs. eca2 mutant vs. eca3 } \\
\text { mutant }\end{array}$ & Functional analysis & [54] \\
\hline 2011 & Barabasz et al. & $E C A 3$ & $\mathrm{Ca}^{2+}$-ATPase & $\begin{array}{c}\text { Tobacco } \\
\text { (Nicotiana tabacum } \\
\text { 'Xanthi') }\end{array}$ & Chlorotic leaf & $\begin{array}{l}\text { Wild type vs. AtECA3 } \\
\text { overexpression line }\end{array}$ & Functional analysis & {$[55]$} \\
\hline 2001 & Kim et al. & AtGluR2 & $\mathrm{Ca}^{2+}$ channel & Arabidopsis thaliana & $\begin{array}{l}\text { Browning and } \\
\text { death of the shoot } \\
\text { apex } \\
\text { Necrosis of leaf tip } \\
\text { Deformation of } \\
\text { leaves }\end{array}$ & $\begin{array}{l}\text { Vector control vs. AtGluR2 } \\
\text { overexpression line }\end{array}$ & Functional analysis & {$[56]$} \\
\hline 2012 & Aouini et al. & $\begin{array}{l}\text { SlGLR1.1 and } \\
\text { SlGLR3.5 } \\
\text { (Solanum } \\
\text { lycoersicum) }\end{array}$ & $\mathrm{Ca}^{2+}$ channel & Arabidopsis thaliana & $\begin{array}{l}\text { Necrosis of the } \\
\text { tips of young } \\
\text { leaves }\end{array}$ & $\begin{array}{l}\text { Wild type vs. SLGLR1.1 over } \\
\text { expressing plant vs. SLGLR3.5 } \\
\text { overexpressing plant }\end{array}$ & Functional analysis & [57] \\
\hline
\end{tabular}


Table 2. Cont.

\begin{tabular}{|c|c|c|c|c|c|c|c|c|}
\hline \multirow{2}{*}{$\begin{array}{l}\text { Year } \\
2007\end{array}$} & \multirow{2}{*}{$\begin{array}{c}\text { Author } \\
\text { Nakagawa et al. }\end{array}$} & \multicolumn{2}{|c|}{ Subject Genes } & \multirow{2}{*}{$\begin{array}{c}\text { Plant Materials } \\
\text { Arabidopsis thaliana }\end{array}$} & \multirow{2}{*}{$\begin{array}{c}\mathrm{Ca}^{2+} \text { Deficiency } \\
\text { Disorder } \\
-\end{array}$} & \multirow{2}{*}{$\begin{array}{c}\text { Main Comparison } \\
\text { Wild-type vs. mca1-null mutant vs. } \\
\text { MCA1-overexpression line }\end{array}$} & \multirow{2}{*}{$\begin{array}{c}\begin{array}{c}\text { Mani } \\
\text { Methods }\end{array} \\
\text { Functional analysis }\end{array}$} & \multirow{2}{*}{$\begin{array}{r}\text { Ref No } \\
{[58]}\end{array}$} \\
\hline & & MCA1 & $\mathrm{Ca}^{2+}$ channel & & & & & \\
\hline 2010 & Yamanaka et al. & $\begin{array}{l}\text { MCA1 and } \\
\text { MCA2 }\end{array}$ & $\mathrm{Ca}^{2+}$ channel & Arabidopsis thaliana & - & $\begin{array}{l}\text { Wild-type vs. mca2-null single } \\
\text { mutant vs. mca1-null and mca2-null } \\
\text { double mutant }\end{array}$ & $\begin{array}{l}\text { Functional analysis } \\
\text { Real-time PCR }\end{array}$ & [59] \\
\hline 2012 & Freitas et al. & PME & The others & $\begin{array}{c}\text { Tomato } \\
\text { (Solanum } \\
\text { lycopersicum) }\end{array}$ & Blossom-end rot & Wild-type vs. $P M E$-silenced plant & Functional analysis & {$[60]$} \\
\hline 2013 & Tanaka et al. & PCaP2 & The others & Arabidopsis thaliana & - & $\begin{array}{l}\text { Wild type vs. NR23 (Root hair-less } \\
\text { line: overexpression of a } 23 \text { amino } \\
\text { acid peptide in the N-terminal region } \\
\text { of } P C a P 2 \text { ) }\end{array}$ & $\begin{array}{l}\text { Functional analysis } \\
\text { Real-time PCR }\end{array}$ & {$[61]$} \\
\hline 2002 & Świędrych et al. & $\begin{array}{c}\text { Solanum } \\
\text { tuberosum } \\
\text { mRNA for } \\
\text { 14-3-3 protein, } \\
\text { clone 20R. } \\
\text { (EMBL/GenBank } \\
\text { database } \\
\text { account no. } \\
\text { X87370) }\end{array}$ & The others & $\begin{array}{l}\text { Potato } \\
\text { (Solanum } \\
\text { tuberosum L. } \\
\text { 'Desiree') }\end{array}$ & - & $\begin{array}{l}\text { Wild type vs. J4 (underexpressing the } \\
\text { potato } 14-3-3 \text { isoform cDNA 20R) }\end{array}$ & Functional analysis & [62] \\
\hline 2019 & Fasani et al. & MYB59 & The others & Arabidopsis thatiana & - & $\begin{array}{c}\text { Wild type vs. myb59 knockout } \\
\text { mutant vs. MYB59 overexpressing } \\
\text { mutant }\end{array}$ & $\begin{array}{c}\text { Functional analysis } \\
\text { Microarray } \\
\text { Real-time PCR }\end{array}$ & [63] \\
\hline
\end{tabular}


In carrot, Park et al. [50] created a CAX1-expressing transgenic line. Compared to the vector controls, this mutation did not alter the morphology and growth characteristics, including those of the edible portion. In contrast, $C A X 1$-expressing carrots accumulated significantly more $\mathrm{Ca}^{2+}$ (1.4-to 1.6-fold) than the vector controls did.

\subsubsection{Effects of Genes Encoding Calreticulin}

Three studies have undertaken functional analysis of the genes encoding calreticulin (CRT) (Table 2). CRT is a $\mathrm{Ca}^{2+}$-binding protein localized in the endoplasmic reticulum lumen, which is a main $\mathrm{Ca}^{2+}$-retaining pool. Persson et al. [51] created transgenic tobacco plants expressing maize (Zea mays) CRT. The CRT-overexpressing tobacco exhibited a twofold increase in ATP-dependent $\mathrm{Ca}^{2+}$ uptake compared to the wild-type line. In addition, they revealed that the ER from the antisense line showed a $40 \%$ decrease in $\mathrm{Ca}^{2+}$ uptake, suggesting that there is a positive correlation between CRT production and ATPdependent $\mathrm{Ca}^{2+}$ uptake. Wyatt et al. [52] also reported that the total $\mathrm{Ca}^{2+}$ concentration in plants, which induced the mGFP5-CRT C-domain fusion protein (GFP: green fluorescent protein), increased by $9-35.7 \%$ compared to the wild type. These results indicate that the expression of the calreticulin C-domain increases the $\mathrm{Ca}^{2+}$ stores.

$\mathrm{Wu}$ et al. [53] investigated the occurrence of $\mathrm{Ca}^{2+}$ deficiency disorders and $\mathrm{Ca}^{2+}$ accumulation in both $s C A X 1$-expressing plants and $s C A X 1$ and $C R T$-co-expressing plants. The authors found that $S C A X 1+C R T$-expressing tobacco and tomato exhibited lower $\mathrm{Ca}^{2+}$ deficiency symptoms (leaf tip necrosis and BER) than the lines expressing $s C A X 1$ did alone. In contrast, there were no significant differences in $\mathrm{Ca}^{2+}$ concentration between the $s C A X+$ $C R T$-expressing and the $S C A X$-expressing lines. These results suggest that co-expression of $C R T$ and $s C A X 1$ enhances the $\mathrm{Ca}^{2+}$ content of plants without any apparent detrimental effects potentially caused by $s C A X 1$ expression.

\subsubsection{Effects of Genes Encoding $\mathrm{Ca}^{2+}$-ATPasess (Pumps)}

Two studies have been conducted on the functional analysis of the genes encoding $\mathrm{P}_{2 \mathrm{~A}}$-type ATPases (ECA) (Table 2). Ca ${ }^{2+}$-ATPases play a role in controlling the $\mathrm{Ca}^{2+}$ efflux from the cytosol to organelles and/or to the apoplast. Under $0.5 \times$ Murashige and Skoog with Mangan $\left(\mathrm{Mn}^{2+}\right)$ omitted $\left(0 \mathrm{Mn}^{2+}\right)$, Mills et al. [54] investigated the $\mathrm{Ca}^{2+}$ concentration in roots of eca3 mutants in which ECA was functionally disrupted. The authors found that, as a result of this disruption, the $\mathrm{Ca}^{2+}$ concentration in the roots of the mutant line was significantly higher than that of the wild type. However, the eca3 mutants showed a marked reduction in growth compared to the wild type. The authors thus suggested that ECA3 is important for $\mathrm{Mn}^{2+}$ and $\mathrm{Ca}^{2+}$ homeostasis. Four years later, Barabasz et al. [55] created AtECA-expressing tobacco. Under $\mathrm{Ca}^{2+}$ deficiency conditions, wild-type plants had chlorotic older leaves, whereas no symptoms were observed in AtECA-expressing tobacco. In contrast, there were no significant differences in the biomass and $\mathrm{Ca}^{2+}$ concentrations of shoots and roots between wild-type and AtECA-expressing plants. These results suggest that $E C A$ expression contributes to increased tolerance to $\mathrm{Ca}^{2+}$ deficiency.

\subsubsection{Effects of Genes Encoding $\mathrm{Ca}^{2+}$ Channels}

Four studies involved functional analysis of the genes encoding $\mathrm{Ca}^{2+}$ channels (Table 2). For the ionotropic glutamate receptor (GLR), which acts as a non-selective $\mathrm{Ca}^{2+}$ channel, Kim et al. [56] reported that an AtGluR2 overexpression line showed $\mathrm{Ca}^{2+}$ deficiency disorders (necrosis and browning of shoot tips and curling of leaves), while no symptoms were observed in the vector control line. In contrast, there was no significant difference in the $\mathrm{Ca}^{2+}$ concentration in the shoots between the control and transgenic plants. The authors suggested that $\mathrm{Ca}^{2+}$ deficiency in transgenic plants is mainly due to reduced utilization of the transported $\mathrm{Ca}^{2+}$. Aouini et al. [57] created transgenic Arabidopsis plants expressing $S$. lycopersicum GLR1.1, GLR3.5 (SlGLR1.1 and SlGLR3.5). Although there were no significant differences in the $\mathrm{Ca}^{2+}$ concentration in the aerial parts of the wild-type and transgenic 
plants, symptoms of $\mathrm{Ca}^{2+}$ deficiency (necrosis of the tips and margins of young leaves, dwarf stature, and curled and deformed leaves) were observed in transgenic plants.

For MCA, which is a $\mathrm{Ca}^{2+}$-permeable stretch-activated channel component, Nakagawa et al. [58] demonstrated that an MCA1-overexpression line accumulated significantly higher $\mathrm{Ca}$ than did the wild-type and mca1-null lines. However, there was no significant difference in $\mathrm{Ca}^{2+}$ uptake between the wild-type and mca1-null lines, meaning that the function of MCA1 remains uncertain. Additionally, Yamanaka et al. [59] created an MCA2-expressing plant. The $\mathrm{Ca}^{2+}$ uptake activity of the MCA2-expressing cells was significantly higher than that of the wild-type. This result suggested that $M C A 2$ functions as a $\mathrm{Ca}^{2+}$ uptake protein in the root.

\subsubsection{Effects of Genes Encoding the Other Proteins}

Freitas et al. [60] created $P M E$-silenced tomato plants (Table 2). Pectin methylesterase (PME) is an enzyme that esterifies the glycan regions within the HG (homogalacturonan) domain of pectin. This enables $\mathrm{Ca}^{2+}$ crosslinking in the cell wall. PME-silenced fruit had a higher total and apoplastic water-soluble $\mathrm{Ca}^{2+}$ concentrations in the pericarp tissue than the wild-type fruit did. Moreover, $P M E$-silenced fruit had a lower incidence of BER than that of the wild-type fruit.

Plasma membrane-associated cation-binding protein 2 (PCaP2) is involved in root hair growth. Tanaka et al. [61] demonstrated that NR23 (root hairless line: overexpression of a 23 amino acid peptide in the N-terminal region of $\mathrm{PCaP2}$ ) did not produce root hairs, and the concentrations of individual minerals, including $\mathrm{Ca}^{2+}$, were relatively low (Table 2). This result indicated that morphological traits, including root hairs, also play significant roles in $\mathrm{Ca}^{2+}$ acquisition.

Świedrych et al. [62] investigated the growth and ion content of 14-3-3-repressed transgenic potato (Table 2). The 14-3-3 protein acts directly with nitrate reductase (NR) and sucrose phosphate synthase (SPS), regulating the process of nitrogen fixation and carbohydrate metabolism. There was no significant difference in dry weight between the wild-type and 14-3-3-repressed transgenic potatoes. However, there was a significant increase in the $\mathrm{Ca}^{2+}$ content of the transgenic potato tubers compared to the wild-type plants, while there were few differences in the concentrations of other minerals (e.g., phosphorus, magnesium, and iron) between the wild-type and transgenic potatoes.

Several studies have also reported effects of transcription factors on $\mathrm{Ca}^{2+}$ accumulation. Fasani et al. [63] investigated the function of MYB59 in Arabidopsis (Table 2). MYB59 is known to be a transcription factor that regulates cell cycle progression and root elongation. The root tips of the myb59 knockout mutant used in this study accumulated significantly higher $\mathrm{Ca}^{2+}$ than the wild type did under $25 \mu \mathrm{M} \mathrm{CdSO}_{4}$. In addition, transcriptome analysis revealed upregulation of calmodulin-like proteins and $\mathrm{Ca}^{2+}$ transporter genes in the myb59 mutant. These results indicate that MYB59 negatively regulates $\mathrm{Ca}^{2+}$ homeostasis and signaling during periods of $\mathrm{Ca}^{2+}$ deficiency.

\subsection{Synthesizing Current Knowledge Regarding the Role of Gene Expression in the Occurrence of} $\mathrm{Ca}^{2+}$ Deficiency Disorders

To determine the role of gene expression in the occurrence of Ca deficiency disorders and/or $\mathrm{Ca}$ accumulation, 37 articles were reviewed in detail (Tables 1 and 2 and Figures 1 and 2). Twenty-six of the thirty-seven reports showed an association between $\mathrm{Ca}$ deficiency and/or Ca accumulation and the expression of $\mathrm{Ca}^{2+}$-movementrelated genes $\left(\mathrm{Ca}^{2+}\right.$ antiporters [27,29,32,35,36,39,42-50,53], calreticulin [30,51-53], $\mathrm{Ca}^{2+}$ ATPase [35,36,39,54,55], $\mathrm{Ca}^{2+}$ channels [55-58], and PME [35,59]). Of the remaining studies, five studies identified QTLs that described variation in tipburn incidence [25,26,33,34,38]. Two studies investigated the causative genes of $\mathrm{Ca}$ deficiency disorders and $\mathrm{Ca}$ accumulation by focusing on morphological traits (leaf shape [28] and root hair production [61]). In addition, other studies identified the relevance of the expression of genes encoding circRNA [31], plant hormones [37], 14-3-3 protein [62], and transcription factors [63] to Ca 
deficiency disorders and/or Ca accumulation in plant organs. Therefore, many genes are likely to be involved in the occurrence of Ca deficiency disorders, but $\mathrm{Ca}^{2+}$-movementrelated genes seem to be the most influential.

Only CAXs $\left(\mathrm{Ca}^{2+} / \mathrm{H}^{+}\right.$antiporter) and CRT (calreticulin) were identified as genes associated with the occurrence of $\mathrm{Ca}$ deficiency disorders in studies obtained from both document retrievals (Searches 1 and 2). In particular, the relevance of CAXs expression to Ca deficiency disorders and/or Ca accumulation has been well-documented [29,32,35,36,39,42-45,48,49,53]. Thus, it is plausible that $C A X s$ act as a causative gene for Ca deficiency disorders in horticultural crops. However, it should be noted that two diametrically opposed hypotheses as to the mechanism by which expression of CAXs is associated with Ca deficiency disorders are advanced by these studies. In Search 2 (Table 2), many studies $[42,43,45,48,49]$ indicated that $C A X 1$-expressing transgenic plants exhibited Ca deficiency disorders because excessive $\mathrm{Ca}$ accumulation in vacuoles inhibited the distribution of $\mathrm{Ca}$ to new leaves and fruits. Based on this phenomenon, two studies suggested $C A X s$ as a causative gene for Ca deficiency disorders using transcriptome analysis [35,36]. In contrast, five studies demonstrated that transgenic plants overexpressing CAXs (CAX1 [46,50], CAX2 [44,47], and $C A X 4$ [43]) did not differ from wild-type plants in morphological traits, and thus that overexpression of $C A X s$ did not cause Ca deficiency disorders in these plants, despite their Ca contents being significantly higher than those of the wild-type. Two studies also concluded that the occurrence of tipburn and BER in Ca deficiency disorder-susceptible lines is due to reduced expression of CAXs compared to resistant lines [29,39]. Although it is clear that $C A X s$ contribute to an increase in Ca acquisition, the effect of CAXs on the occurrence of $\mathrm{Ca}$ deficiency disorders needs to be investigated in more detail. It is particularly important that future studies demonstrate localized $\mathrm{Ca}$ accumulation and gene expression and carefully evaluate their role in Ca deficiency disorders.

Compared with CAXs, the function of CRT in Ca deficiency disorders and/or Ca accumulation is not well-documented. However, this systematic review indicated that expression of $C R T$ likely enhances $\mathrm{Ca}$ accumulation and decreases the occurrence of $\mathrm{Ca}$ deficiency disorders [51-53]. In addition, a single study by Su et al. [30], which involved both QTL analysis and functional analysis, indicated that BrCRT2 is a candidate gene for controlling tipburn in Chinese cabbage. It is important that future studies conduct both exhaustive gene expression and functional analyses to identify the causative genes of $\mathrm{Ca}$ deficiency disorders, as in the report by Su et al. [30]. This systematic review also suggests that the causative genes of Ca deficiency disorders differ between different horticultural crops and cultivars.

Additionally, this systematic review suggests that expression of $E C A 3$ plays a contributive role in mitigating the occurrence of Ca deficiency disorders [55,60], and that overexpression of GLRs and PME may cause Ca deficiency disorders [56,57]. However, the effects of genes for which few studies on Ca deficiency disorders exist need to be further investigated. In addition, it is known that plant hormones affect the occurrence of $\mathrm{Ca}$ deficiency disorders [64-66]. In this systematic review, some reports indicated that plant hormones and the expression of related genes affected the occurrence of Ca deficiency disorders $[31,36,37]$. Quantification of not only Ca distribution, but also plant hormone localization, may provide further understanding of the mechanism of Ca deficiency disorders in plants.

\section{Perspectives}

We do not yet have fully systematized knowledge of the causative genes for Ca deficiency disorders in different horticulture crops. However, this systematic review showed that many studies, in various plant systems and from various perspectives, have been conducted to identify the causative genes for Ca deficiency disorders. It is likely that the relationship between gene expression and Ca distribution will be systematically understood, and the mechanism of occurrence of Ca deficiency disorders in horticulture crops will be explained genetically in the near future. We hope that the knowledge synthesized 
in this systematic review will contribute to the accumulation of further knowledge and elucidation of the causes of Ca deficiency disorders.

\section{Conclusions}

To synthesize current knowledge regarding the role of gene expression in the occurrence of $\mathrm{Ca}^{2+}$ deficiency disorders, we conducted a systematic literature review using PRISMA. In total, 37 articles were extracted in this review. In particular, the effects of the expression of $C A X s$ and $C R T$ on the occurrence of $\mathrm{Ca}^{2+}$ deficiency disorders were well demonstrated. However, the causative genes for $\mathrm{Ca}^{2+}$ deficiency disorders in each horticulture crop are not clear. We hope that the knowledge synthesized in this systematic review will contribute to the accumulation of further knowledge and elucidation of the causes of $\mathrm{Ca}^{2+}$ deficiency disorders.

Author Contributions: Conceptualization, T.K. and H.W.; methodology, T.K.; validation, T.K. and H.W.; investigation, T.K. and H.W.; resources, T.K. and H.W.; data curation, T.K.; writing-original draft preparation, T.K.; writing-review and editing, H.W.; visualization, T.K.; supervision, T.K.; project administration, T.K. and H.W.; funding acquisition, T.K. All authors have read and agreed to the published version of the manuscript.

Funding: This research was funded by JSPS KAKENHI (Grant Number JP19K15830).

Conflicts of Interest: The authors declare no conflict of interest.

\section{References}

1. Olle, M.; Bender, I. Causes and control of calcium deficiency disorders in vegetables: A review. J. Hortic. Sci. Biotechnol. 2009, 84, 577-584. [CrossRef]

2. Hartz, T.K.; Johnstone, P.R.; Smith, R.F.; Cahn, M.D. Soil calcium status unrelated to tipburn of romaine lettuce. HortScience 2007, 42, 1681-1684. [CrossRef]

3. Kuronuma, T.; Ando, M.; Watanabe, H. Tipburn Incidence and Ca acquisition and distribution in lisianthus (Eustoma grandiflorum (Raf.) Shinn.) cultivars under different Ca concentrations in nutrient solution. Agronomy 2020, 10, 216. [CrossRef]

4. Hagassou, D.; Francia, E.; Ronga, D.; Buti, M. Blossom end-rot in tomato (Solanum lycopersicum L.): A multi-disciplinary overview of inducing factors and control strategies. Sci. Hortic. 2019, 249, 49-58. [CrossRef]

5. Sago, Y. Effects of light intensity and growth rate on tipburn development and leaf calcium concentration in butterhead lettuce. HortScience 2016, 51, 1087-1091. [CrossRef]

6. Hernandez, J.; Soriano, T.; Morales, M.I.; Castilla, N. Row covers for quality improvement of Chinese cabbage (Brassica rapa subsp. pekinensis). N. Z. J. Crop. Hortic. Sci. 2004, 32, 379-388. [CrossRef]

7. Mason, G.F.; Guttridge, C.G. The influence of relative humidity and nutrition on leaf tipburn of strawberry. Sci. Hortic. 1975, 3, 339-349. [CrossRef]

8. Kuronuma, T.; Watanabe, Y.; Ando, M.; Watanabe, H. Tipburn severity and calcium distribution in lisianthus (Eustoma grandiflorum (Raf.) Shinn.) cultivars under different relative air humidity conditions. Agronomy 2018, 8, 218. [CrossRef]

9. Tibbitts, T.W.; Rao, R.R. Light intensity and duration in the development of lettuce tipburn. Am. Soc. Hortic. Sci. 1968, 93, 454-461.

10. Goto, E.; Takakura, T. Prevention of lettuce tipburn by supplying air to inner leaves. Trans. ASAE 1992, 35, 641-645. [CrossRef]

11. Shibata, T.; Iwao, K.; Takano, T. Effect of vertical air flowing on lettuce growing in a plant factory. Greenh. Environ. Control Autom. 1994, 399, 175-182. [CrossRef]

12. García Bossi, J.; Kumar, K.; Barberini, M.L.; Domínguez, G.D.; Rondón Guerrero, Y.D.C.; Marino-Buslje, C.; Obertello, M.; Muschietti, J.P.; Estevez, J.M. The role of P-type IIA and P-type IIB Ca ${ }^{2+}$-ATPases in plant development and growth. J. Exp. Bot. 2020, 71, 1239-1248. [CrossRef]

13. Swarbreck, S.M.; Colaço, R.; Davies, J.M. Plant calcium-permeable channels. Plant Physiol. 2013, 163, 514-522. [CrossRef] [PubMed]

14. Zielinski, R.E. Calmodulin and calmodulin-binding proteins in plants. Annu. Rev. Plant Biol. 1998, 49, 697-725. [CrossRef] [PubMed]

15. Conn, S.J.; Gilliham, M.; Athman, A.; Schreiber, A.W.; Baumann, U.; Moller, I.; Cheng, N.H.; Stancombe, M.A.; Hirschi, K.D.; Webb, A.A.R.; et al. Cell-specific vacuolar calcium storage mediated by CAX1 regulates apoplastic calcium concentration, gas exchange, and plant productivity in Arabidopsis. Plant Cell 2011, 23, 240-257. [CrossRef]

16. Yu, H.; Yan, J.; Du, X.; Hua, J. Overlapping and differential roles of plasma membrane calcium ATPases in Arabidopsis growth and environmental responses. J. Exp. Bot. 2018, 69, 2693-2703. [CrossRef]

17. Costa, A.; Navazio, L.; Szabo, I. The contribution of organelles to plant intracellular calcium signalling. J. Exp. Bot. 2018, 69, 4175-4193. [CrossRef] 
18. Stael, S.; Wurzinger, B.; Mair, A.; Mehlmer, N.; Vothknecht, U.C.; Teige, M. Plant organellar calcium signalling: An emerging field. J. Exp. Bot. 2012, 63, 1525-1542. [CrossRef]

19. White, P.J.; Broadley, M.R. Calcium in plants. Ann. Bot. 2003, 92, 487-511. [CrossRef]

20. Hirschi, K.D. Expression of Arabidopsis CAX1 in tobacco: Altered calcium homeostasis and increased stress sensitivity. Plant Cell 1999, 11, 2113-2122. [CrossRef]

21. Park, S.; Cheng, N.H.; Pittman, J.K.; Yoo, K.S.; Park, J.; Smith, R.H.; Hirschi, K.D. Increased calcium levels and prolonged shelf life in tomatoes expressing Arabidopsis $\mathrm{H}^{+} / \mathrm{Ca}^{2+}$ transporters. Plant Physiol. 2005, 139, 1194-1206. [CrossRef]

22. Moher, D.; Liberati, A.; Tetzlaff, J.; Altman, D.G.; The Prisma Group. Preferred reporting items for systematic reviews and meta-analyses: The PRISMA statement. PLoS Med. 2009, 6, e1000097. [CrossRef]

23. Jo, H.; Song, C.; Miyazaki, Y. Physiological benefits of viewing nature: A systematic review of indoor experiments. Int. J. Environ. Res. Public Health 2019, 16, 4739. [CrossRef]

24. El Bilali, H. The multi-level perspective in research on sustainability transitions in agriculture and food systems: A systematic review. Agriculture 2019, 9, 74. [CrossRef]

25. Rahman, M.S.; Di, L. A systematic review on case studies of remote-sensing-based flood crop loss assessment. Agriculture 2020, 10, 131. [CrossRef]

26. Jayawardhana, D.N.; Cao, L.T.T.; Yeargin, T.A.; Gibson, K.E.; Fraser, A.M. The Relationship between Environmental Characteristics and Risk Management Practices on Produce Farms: A Systematic Literature Review. Agriculture 2020, 10, 577. [CrossRef]

27. Jenni, S.; Truco, M.J.; Michelmore, R.W. Quantitative trait loci associated with tipburn, heat stress-induced physiological disorders, and maturity traits in crisphead lettuce. Theor. Appl. Genet. 2013, 126, 3065-3079. [CrossRef] [PubMed]

28. Macias-González, M.; Truco, M.J.; Bertier, L.D.; Jenni, S.; Simko, I.; Hayes, R.J.; Michelmore, R.W. Genetic architecture of tipburn resistance in lettuce. Theor. Appl. Genet. 2019, 132, 2209-2222. [CrossRef]

29. Macias-González, M.; Truco, M.J.; Han, R.; Jenni, S.; Michelmore, R.W. High resolution genetic dissection of the major QTL for tipburn resistance in lettuce, Lactuca sativa. G3 Genes Genomes Genet. 2021, 11, jkab097. [CrossRef]

30. Seki, K.; Komatsu, K.; Tanaka, K.; Hiraga, M.; Kajiya-Kanegae, H.; Matsumura, H.; Uno, Y. A CIN-like TCP transcription factor (LsTCP4) having retrotransposon insertion associates with a shift from Salinas type to Empire type in crisphead lettuce (Lactuca sativa L.). Hortic. Res. 2021, 7, 15. [CrossRef]

31. Su, T.; Yu, S.; Yu, R.; Zhang, F.; Yu, Y.; Zhang, D.; Zhao, X.; Wang, W. Effects of endogenous salicylic acid during calcium deficiency-induced tipburn in Chinese cabbage (Brassica rapa L. Ssp. pekinensis). Plant Mol. Biol. Rep. 2016, 34, 607-617. [CrossRef] [PubMed]

32. Su, T.; Li, P.; Wang, H.; Wang, W.; Zhao, X.; Yu, Y.; Zhang, D.; Yu, S.; Zhang, F. Natural variation in a calreticulin gene causes reduced resistance to $\mathrm{Ca}^{2+}$ deficiency-induced tipburn in Chinese cabbage (Brassica rapa ssp. pekinensis). Plant Cell Environ. 2019, 42, 3044-3060. [CrossRef] [PubMed]

33. Wang, W.; Wang, J.; Wei, Q.; Li, B.; Zhong, X.; Hu, T.; Hu, H.; Bao, C. Transcriptome-wide identification and characterization of circular RNAs in leaves of Chinese cabbage (Brassica rapa L. ssp. pekinensis) in response to calcium deficiency-induced tip-burn. Sci. Rep. 2019, 9, 14544. [CrossRef] [PubMed]

34. Lee, J.; Park, I.; Lee, Z.W.; Kim, S.W.; Baek, N.; Park, H.S.; Park, S.U.; Kwon, S.Y.; Kim, H. Regulation of the major vacuolar Ca ${ }^{2+}$ transporter genes, by intercellular $\mathrm{Ca}^{2+}$ concentration and abiotic stresses, in tip-burn resistant Brassica oleracea. Mol. Biol. Rep. 2013, 40, 177-188. [CrossRef] [PubMed]

35. Lee, J.; Kim, J.; Choi, J.P.; Lee, M.; Kim, M.K.; Lee, Y.H.; Hur, Y.; Nou, I.S.; Park, S.U.; Min, S.R.; et al. Intracellular Ca ${ }^{2+}$ and K ${ }^{+}$ concentration in Brassica oleracea leaf induces differential expression of transporter and stress-related genes. BMC Genom. 2016, 17, 211. [CrossRef]

36. Gonzalo, M.J.; Li, Y.C.; Chen, K.Y.; Gil, D.; Montoro, T.; Nájera, I.; Baixauli, C.; Granell, A.; Monforte, A.J. Genetic Control of Reproductive Traits in Tomatoes Under High Temperature. Front. Plant Sci. 2020, 11, 326. [CrossRef]

37. Kuronuma, T.; Watanabe, H. Search for candidate genes causing the excessive Ca accumulation in roots of tipburn-damaged lisianthus (Eustoma grandiflorum) cultivars. Agriculture 2021, 11, 254. [CrossRef]

38. Freitas, S.T.; Jiang, C.Z.; Mitcham, E.J. Mechanisms involved in calcium deficiency development in tomato fruit in response to gibberellins. J. Plant Growth Regul. 2012, 31, 221-234. [CrossRef]

39. Freitas, S.T.; Martinelli, F.; Feng, B.; Reitz, N.F.; Mitcham, E.J. Transcriptome approach to understand the potential mechanisms inhibiting or triggering blossom-end rot development in tomato fruit in response to plant growth regulators. J. Plant Growth Regul. 2018, 37, 183-198. [CrossRef]

40. Uozumi, A.; Ikeda, H.; Hiraga, M.; Kanno, H.; Nanzyo, M.; Nishiyama, M.; Kanahama, K.; Kanayama, Y. Tolerance to salt stress and blossom-end rot in an introgression line, IL8-3, of tomato. Sci. Hortic. 2012, 138, 1-6. [CrossRef]

41. Ikeda, H.; Shibuya, T.; Nishiyama, M.; Nakata, Y.; Kanayama, Y. Physiological mechanisms accounting for the lower incidence of blossom-end rot in tomato introgression line IL8-3 fruit. Hortic. J. 2017, 86, 327-333. [CrossRef]

42. Kuronuma, T.; Saotome, M.; Ando, M.; Watanabe, H. Excessive calcium accumulation in the roots is a key factor in tipburn incidence under high Ca supply in lisianthus (Eustoma grandiflorum) cultivars. Agronomy 2020, 10, 1123. [CrossRef]

43. Kuronuma, T.; Kinoshita, N.; Ando, M.; Watanabe, H. Difference of Ca distribution before and after the onset of tipburn in lisianthus [Eustoma grandiflorum (Raf.) Shinn.] cultivars. Sci. Hortic. 2020, 261, 108911. [CrossRef] 
44. Chung, M.Y.; Han, J.S.; Giovannoni, J.; Liu, Y.; Kim, C.K.; Lim, K.B.; Chung, J.D. Modest calcium increase in tomatoes expressing a variant of Arabidopsis cation $/ \mathrm{H}^{+}$antiporter. Plant Biotechnol. Rep. 2010, 4, 15-21. [CrossRef]

45. Freitas, S.T.; Padda, M.; Wu, Q.; Park, S.; Mitcham, E.J. Dynamic alternations in cellular and molecular components during blossom-end rot development in tomatoes expressing sCAX1, a constitutively active $\mathrm{Ca}^{2+} / \mathrm{H}^{+}$antiporter from Arabidopsis. Plant Physiol. 2011, 156, 844-855. [CrossRef] [PubMed]

46. Park, S.; Kang, T.S.; Kim, C.K.; Han, J.S.; Kim, S.; Smith, R.H.; Pike, L.M.; Hirschi, K.D. Genetic manipulation for enhancing calcium content in potato tuber. J. Agric. Food Chem. 2005, 53, 5598-5603. [CrossRef] [PubMed]

47. Kim, C.K.; Han, J.S.; Lee, H.S.; Oh, J.Y.; Shigaki, T.; Park, S.H.; Hirschi, K. Expression of an Arabidopsis CAX2 variant in potato tubers increases calcium levels with no accumulation of manganese. Plant Cell Rep. 2006, 25, 1226-1232. [CrossRef] [PubMed]

48. Zorrilla, C.; Schabow, J.E.; Chernov, V.; Palta, J.P. CAX1 vacuolar antiporter overexpression in potato results in calcium deficiency in leaves and tubers by sequestering calcium as calcium oxalate. Crop. Sci. 2019, 59, 176-189. [CrossRef]

49. Gao, H.; Wu, X.; Zorrilla, C.; Vega, S.E.; Palta, J.P. Fractionating of calcium in tuber and leaf tissues explains the calcium deficiency symptoms in potato plant overexpressing CAX1. Front. Plant Sci. 2020, 10, 1793. [CrossRef]

50. Park, S.; Kim, C.K.; Pike, L.M.; Smith, R.H.; Hirschi, K.D. Increased calcium in carrots by expression of an Arabidopsis $\mathrm{H}^{+} / \mathrm{Ca}^{2+}$ transporter. Mol. Breed. 2004, 14, 275-282. [CrossRef]

51. Persson, S.; Wyatt, S.E.; Love, J.; Thompson, W.F.; Robertson, D.; Boss, W.F. The $\mathrm{Ca}^{2+}$ status of the endoplasmic reticulum is altered by induction of calreticulin expression in transgenic plants. Plant Physiol. 2001, 126, 1092-1104. [CrossRef] [PubMed]

52. Wyatt, S.E.; Tsou, P.L.; Robertson, D. Expression of the high capacity calcium-binding domain of calreticulin increases bioavailable calcium stores in plants. Transgenic Res. 2002, 11, 1-10. [CrossRef]

53. Wu, Q.; Shigaki, T.; Han, J.S.; Kim, C.K.; Hirschi, K.D.; Park, S. Ectopic expression of a maize calreticulin mitigates calcium deficiency-like disorders in sCAX1-expressing tobacco and tomato. Plant Mol. Biol. 2012, 80, 609-619. [CrossRef]

54. Mills, R.F.; Doherty, M.L.; López-Marqués, R.L.; Weimar, T.; Dupree, P.; Palmgren, M.G.; Pittman, J.K.; Williams, L.E. ECA3, a Golgi-localized P2A-type ATPase, plays a crucial role in manganese nutrition in Arabidopsis. Plant Physiol. 2008, 146, 116-128. [CrossRef] [PubMed]

55. Barabasz, A.; Mills, R.F.; Trojanowska, E.; Williams, L.E.; Antosiewicz, D.M. Expression of AtECA3 in tobacco modifies its responses to manganese, zinc and calcium. Environ. Exp. Bot. 2011, 72, 202-209. [CrossRef]

56. Kim, S.A.; Kwak, J.; Jae, S.K.; Wang, M.H.; Nam, H. Overexpression of the AtGluR2 gene encoding an Arabidopsis homolog of mammalian glutamate receptors impairs calcium utilization and sensitivity to ionic stress in transgenic plants. Plant Cell Physiol. 2001, 42, 74-84. [CrossRef]

57. Aouini, A.; Hernould, M.; Ariizumi, T.; Matsukura, C.; Ezura, H.; Asamizu, E. Overexpression of the tomato glutamate receptor-like genes SlGLR1.1 and SlGLR3.5 hinders $\mathrm{Ca}^{2+}$ utilization and promotes hypersensitivity to $\mathrm{Na}^{+}$and $\mathrm{K}^{+}$stresses. Plant Biotechnol. 2012, 29, 229-235. [CrossRef]

58. Nakagawa, Y.; Katagiri, T.; Shinozaki, K.; Qi, Z.; Tatsumi, H.; Furuichi, T.; Kishigami, A.; Sokabe, M.; Kojima, I.; Sato, S.; et al. Arabidopsis plasma membrane protein crucial for $\mathrm{Ca}^{2+}$ influx and touch sensing in roots. Proc. Natl. Acad. Sci. USA 2007, 104, 3639-3644. [CrossRef]

59. Yamanaka, T.; Nakagawa, Y.; Mori, K.; Nakano, M.; Imamura, T.; Kataoka, H.; Terashima, A.; Iida, K.; Kojima, I.; Katagiri, T.; et al. MCA1 and MCA2 that mediate $\mathrm{Ca}^{2+}$ uptake have distinct and overlapping roles in Arabidopsis. Plant Physiol. 2010, 152, 1284-1296. [CrossRef] [PubMed]

60. Freitas, S.T.; Handa, A.K.; Wu, Q.; Park, S.; Mitcham, E.J. Role of pectin methylesterases in cellular calcium distribution and blossom-end rot development in tomato fruit. Plant J. 2012, 71, 824-835. [CrossRef]

61. Tanaka, N.; Kato, M.; Tomioka, R.; Kurata, R.; Fukao, Y.; Aoyama, T.; Maeshima, M. Characteristics of a root hair-less line of Arabidopsis thaliana under physiological stresses. J. Exp. Bot. 2014, 65, 1497-1512. [CrossRef]

62. Świędrych, A.; Prescha, A.; Matysiak-Kata, I.; Biernat, J.; Szopa, J. Repression of the 14-3-3 gene affects the amino acid and mineral composition of potato tubers. J. Agric. Food Chem. 2002, 50, 2137-2141. [CrossRef] [PubMed]

63. Fasani, E.; DalCorso, G.; Costa, A.; Zenoni, S.; Furini, A. The Arabidopsis thaliana transcription factor MYB59 regulates calcium signalling during plant growth and stress response. Plant Mol. Biol. 2019, 99, 517-534. [CrossRef]

64. Aloni, B.; Pashkar, T.; Libel, R. The possible involvement of gibberellins and calcium in tipburn of Chinese cabbage: Study of intact plants and detached leaves. Plant Growth Regul. 1986, 4, 3-11. [CrossRef]

65. Pressman, E.; Aviram, H. Inhibition of flowering in Chinese cabbage by applying heat and growth retardants to transplants. Plant Growth Regul. 1986, 4, 87-94. [CrossRef]

66. Pressman, E.; Shaked, R.; Arcan, L. The effect of flower-inducing factors on leaf tipburn formation in Chinese cabbage. J. Plant Physiol. 1993, 141, 210-214. [CrossRef] 